\title{
Automatic Evaluation of Faces Predict Mayor Election Outcomes in Brazil
}

\author{
Sergio Da Silva*, Joao Felipe de Novais \\ Department of Economics, Federal University of Santa Catarina, Florianopolis, Brazil \\ Email: *professorsergiodasilva@gmail.com
}

How to cite this paper: Da Silva, S. and de Novais, J.F. (2017) Automatic Evaluation of Faces Predict Mayor Election Outcomes in Brazil. Open Access Library Journal, 4: e3300.

http://dx.doi.org/10.4236/oalib.1103300

Received: December 14, 2016

Accepted: January 2, 2017

Published: January 5, 2017

Copyright $\odot 2017$ by authors and Open Access Library Inc.

This work is licensed under the Creative Commons Attribution International License (CC BY 4.0).

http://creativecommons.org/licenses/by/4.0/

\section{(c) (i) Open Access}

\begin{abstract}
Elections can be decided on the basis of automatic evaluations of a candidate's face that take less than one second. These inferences are specific to competence and they could predict better than chance 68.8 percent of the US Senate race results in 2004. Such a finding suggests fast, unreflective trait inferences can contribute to voting choices. We replicated this finding for the 2012 and 2016 municipal elections that took place in the southern Brazil state of Santa Catarina. Mayors could have been elected partially by automatic perceptions of competence.
\end{abstract}

\section{Subject Areas}

Behavioral Economics, Politics, Psychology

\section{Keywords}

Voting Behavior, Automatic Face Evaluation, Election Outcomes, Nonverbal Behavior, Field Experiment

\section{Introduction}

Elections can be decided on the basis of automatic evaluations of a candidate's face that take less than one second [1]. These inferences are specific to competence and they could predict better than chance 68.8 percent of the US Senate race results in 2004. Such a finding suggests that fast, unreflective trait inferences can contribute to voting choices. This is worrying because it is tacitly assumed that voting should be based primarily on deliberate choices.

We conducted a field experiment to test this hypothesis for the 2012 and 2016 municipal elections that took place in the southern Brazil state of Santa Catarina. We find the hypothesis cannot be dismissed from these data. Automatic perceptions of competence encoded on a candidate's face could have played a role in 
the two mayoral elections.

According to the dual-system approach to higher cognition processes [2] [3], two systems compete for control of our inferences and actions: 1) a large set of subsystems that operate autonomously in response to its own triggering stimuli ("System 1"); and 2) an analytic processing system ("System 2"). System 1 is similar to a Swiss army knife in that it is made up of input modules related to specific-domain knowledge that are evolutionarily adapted for solving particular problems. System 1 controls intuitive decisions that are fast and automatic. System 2 is non-modular and is responsible for abstract reasoning and the use of hypotheses. System 2 is deliberative but slow. System 1 is evolutionarily older than System 2 and thus decisions based on System 1 have an evolutionary logic from the gene's perspective that sometimes seems irrational from the vehicle point of view [4].

People automatically make personality inferences from faces irrespective of their accuracy, and this suggests such inferences originate in functionally adaptive mechanisms [5]. One implication of the dual-process theory of mind is that impressions can be formed in the very first encounter with a person, and this can have subjectively unrecognized effects on subsequent deliberate judgments [1]. If the person is a politician, competence is one of the most important trait attributes to be assessed [6].

This study considered two samples. The first was for the 2012 municipal elections in the state of Santa Catarina. Four years after the election, participants made a binary choice between two candidate's faces and evaluated their competency. Then, the results were compared with the actual proportion of votes a candidate received. The second sample was for the 2016 elections for mayors. This time judgments were made prior to the election and participants were asked to rate a candidate's face considering 11 personality traits [7]. The ratings were then thereafter compared to the mayors actually elected.

The rest of the paper is organized as follows: Section 2 describes the materials and methods employed in this research; Section 3 shows the results; and Section 4 concludes the study.

\section{Materials and Methods}

All the data from both elections were taken from the site of the Brazilian Higher Electoral Court (Tribunal Superior Eleitoral) located at http://www.tse.jus.br/. The data include mainly the results and candidates' photographs and are in the public domain. For their choices, participants were offered digital forms that were accessed electronically on computers or mobile devices. The questionnaires were displayed using the Typeform platform (https://www.typeform.com/).

Because the first experiment occurred after the 2012 elections, we randomly asked 55 participants to make a binary choice between a winner and a runner-up. No participants declared to know any of the candidates, apart obviously from those of his or her own municipality, in which case a choice was discarded. Candidates ranked below third place were then dismissed, wherever they existed. 
The dependent variable was the relative proportion of votes received by the winner:

$$
y=\frac{\text { winner votes }}{\text { winner votes }+ \text { runner-up votes }}
$$

From the original 295 municipalities, we ended up with 270, after removing the municipalities with only one candidate. Thus, for the 270 pairs of candidates, the explanatory variable was the frequency of choices for the candidate considered more competent by the participants relative to the total number of answers they provided $n$ :

$$
x=\frac{f(\text { faces inspiring competence) }}{n}
$$

At the end of a questionnaire, each participant was asked to give his or her age and gender, whether he or she was a student, and the average time he or she usually spent watching television. Automatic face evaluations are expected to be stronger for non-students and those showing signs of addiction to TV. However, we found these characteristics did not matter for our results. To encourage participation, a computer printer was raffled among participants. Figure 1 shows a screen selected from the sample.

As for the second experiment that took place prior to the 2016 elections, we considered only the largest 30 constituencies. After a late withdrawal of a candidate from the town of Brusque, the sample was reduced to 29. From the original 120 mayoral candidates, nine were disqualified for charges of electoral fraud on the eve of the ballots being cast. This generated a mismatch between the 111 candidates who ended up running and the 120 photographs previously displayed on the questionnaires. However, this created no significant problems in light of the fact that the choices of faces were made independently from (that is, before) the actual election.

In total, 67 participants partook in our study. We approached them on three separate occasions. In the first, we got 32 answers; in the second, 19 answers; and

\section{Qual pessoa é a mais competente?}
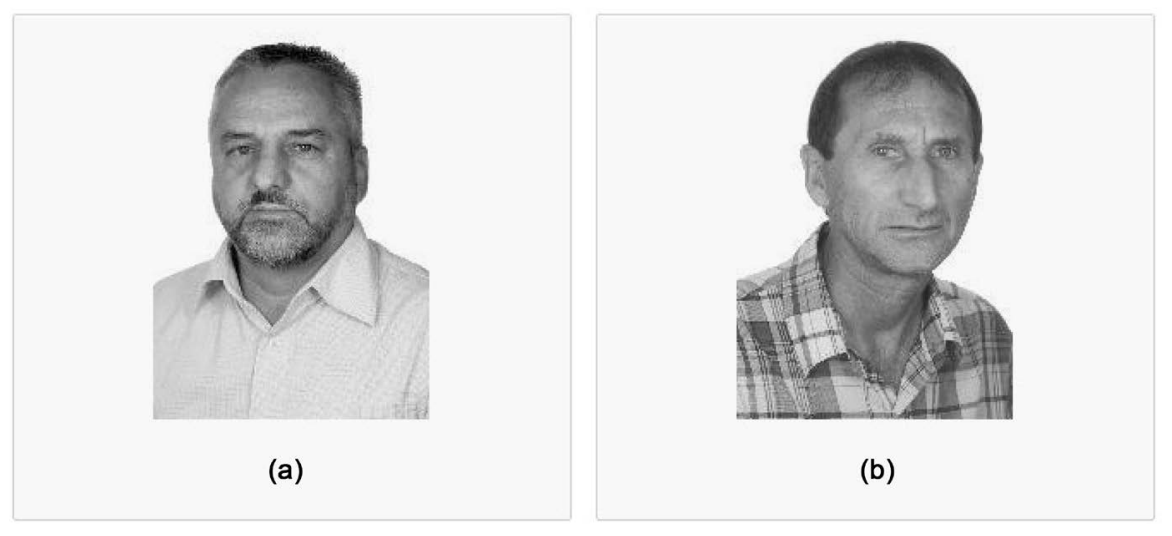

Figure 1. A screen selected from the digital questionnaires of the first experiment showing a winner and a runner-up from the sample of candidates participating in the 2012 municipal elections in Santa Catarina. It asked: "Which person is more competent?". 
in the third, 16 answers. On each occasion, we raffled a mystery novel book by a local author to incentivize their engagement in answering the questionnaires. We showed the participants 11 personality traits derived from the big five traits (openness to experience; conscientiousness; agreeableness; stability; extraversion) [8] [9] for them to ascribe to the candidates using a Likert scale (strongly disagree; disagree; neither agree nor disagree; agree; strongly agree). Table 1 shows the big five traits and 10 derived traits, one positive and one negative for each. Because competence is key for politicians, we considered this characteristic to add the 10 displayed on Table 1, despite the fact that competence is a trait expressing conscientiousness. For every candidate, we computed the average of the trait evaluations from each of the 67 participants. Figure 2 shows a selected screen from the digital questionnaires.

Table 1. Personality traits.

\begin{tabular}{cll}
\hline Big five traits & Positive expressions of the traits & Negative expressions of the traits \\
\hline Openness to experience & 1) Broad-mindedness & 2) Traditionalism \\
Conscientiousness & 3) Reliability & 4) Untidiness \\
Agreeableness & 5) Kindness & 6) Aggressiveness \\
Neuroticism & 7) Anxiety & 8) Emotional stability \\
Extraversion & 9) Gregariousness & 10) Loneliness
\end{tabular}

Numa escala de 1 a 5 , avalie o perfil da pessoa abaixo para cada característica. Leve o menor tempo possivel

Use as teclas de 1 a 5 para facilitar.

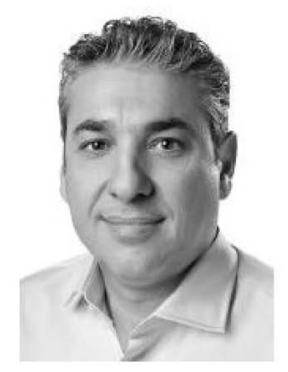

a. aberto a novas ideias

1

DISCORDO TOTALMENTE
2

3

NEUTRO
4

CONCORDO TOTALMENTE

Figure 2. A screen selected from the digital questionnaires of the second experiment. It shows the face of a candidate along with a personality trait for a participant to judge using a Likert scale. The questionnaires were applied before the 2016 municipal elections in Santa Catarina. It asked: "Using the scale below, evaluate how much this personality characteristic applies to this person. Please choose quickly. a) broad-minded." 
All the data are available at Figshare

(https://dx.doi.org/10.6084/m9.figshare.4309673.v1).

\section{Results}

As for the first experiment, automatic face evaluations successfully predicted the winners of 149 municipalities, which means 55.19 percent of the total 270. Automatic evaluation of faces predicted better than chance. However, this result is to be taken with caution because the correlation between variables $x$ and $y$ was very low and still nonsignificant. Lack of correlation may or may not be related to the sample size. After all, from a population of almost 3 million voters, we are considering only a sample of 55 individuals.

The suggestive but inconclusive results of the first experiment thus prompted us to conceive the aforementioned second experiment, which follows the lines of Ref [7].

Table 2 shows the results of the second experiment and compares them to the benchmark study [7]. Overall, our sample replicates the previous study for the selected personality traits displayed on Table 2. In particular, 11 out of the 29 elected mayors received a higher rate from the competence trait. Inferred votes from faces using the Likert scale from 1 to 5 for the competence trait presented a mean equals to 3.3402 with a standard deviation of 0.2088 for the winners. This was above the measure for all the candidates (mean $=3.2488$; standard deviation $=0.2765)$.

Figure 3 shows the actual votes received by a mayoral candidate in the 2016 elections in Santa Catarina (vertical axis) versus the inferred votes from faces relative to the total answers provided by the 67 participants (horizontal axis). The straight line is the linear fit.

\section{Conclusions}

This study evaluated the hypothesis that people vote by automatic evaluations of a candidate's face, mainly automatic perceptions of competence [1] [7]. We found this hypothesis cannot be dismissed from our data, which considered the

Table 2. Comparison of our results with those of the benchmark study.

\begin{tabular}{ccc}
\hline & \multicolumn{2}{c}{ Correlation } \\
\hline Trait & Olivola \& Todorov (2010) [7] & $\begin{array}{c}\text { This study } \\
(2016 \text { elections })\end{array}$ \\
\hline Openness to experience (Traditionalism) & $0.23^{*}$ & $0.32(p<0.05)$ \\
Conscientiousness (Competence) & $0.56(p<0.01)$ & $0.30(p<0.05)$ \\
Conscientiousness (Reliability) & $0.36(p<0.01)$ & $0.25(p<0.05)$ \\
Conscientiousness (Untidiness) & $-0.33(p<0.01)$ & $-0.27(p<0.05)$ \\
Agreeableness (Aggressiveness) & $0.13^{*}$ & $-0.23(p<0.05)$ \\
Neuroticism (Emotional stability) & $0.45(p<0.01)$ & $0.2(p<0.05)$ \\
\hline
\end{tabular}

*nonsignificant. 


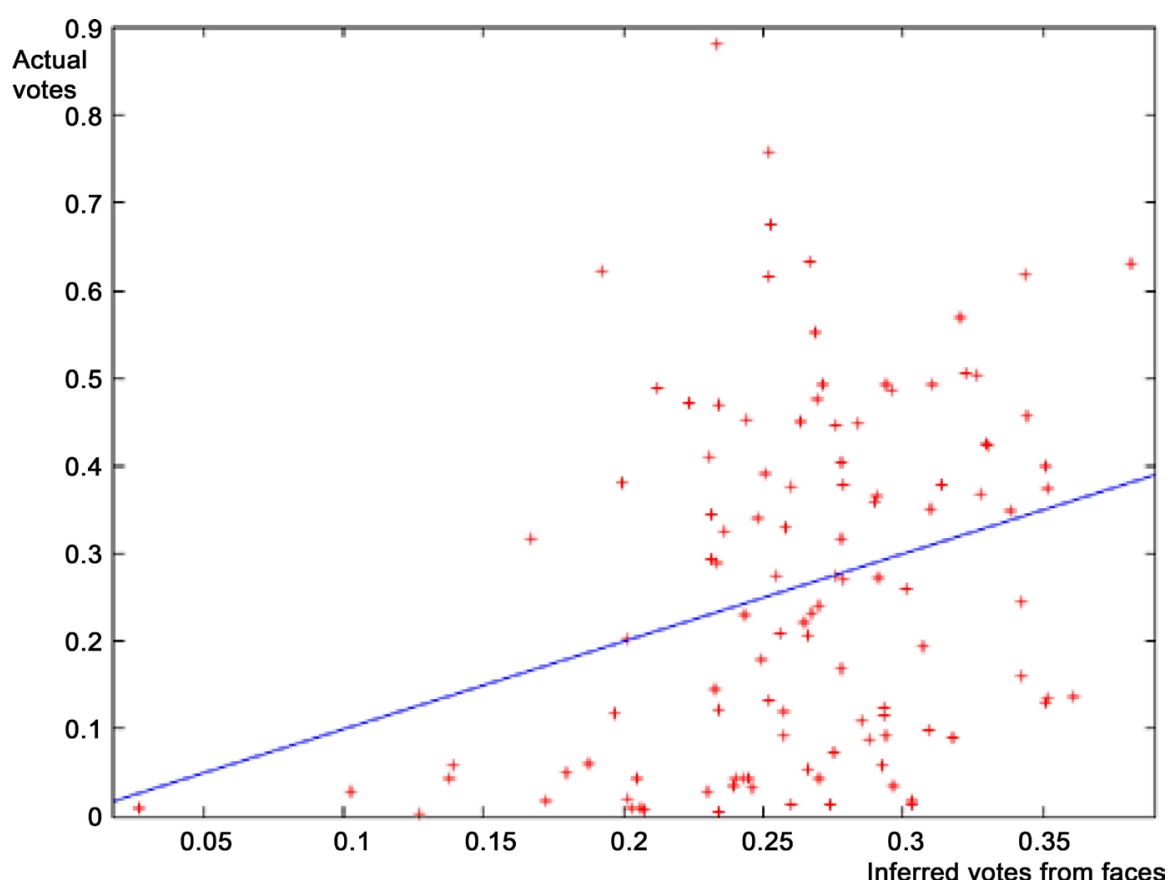

Figure 3. Actual votes received by a mayoral candidate in the 2016 elections in Santa Catarina (vertical axis) versus the inferred votes from faces relative to total answers (horizontal axis). The straight line is the linear fit.

2012 and 2016 municipal elections that took place in the southern Brazil state of Santa Catarina.

In the first experiment that occurred after the 2012 elections, we randomly asked 55 participants to make a binary choice between a winner and a runner-up. They made correct choices in 55.19 percent of the total, which suggests automatic evaluation of faces predicted better than chance. However, correlation was low and nonsignificant.

Nevertheless, in the second experiment we finely replicated a benchmark study [7] using 67 participants. We found that 11 out of the 29 elected mayors in the 2016 elections received a higher rating for the competence trait. Inferred votes from faces using a Likert scale for the competence trait were, on average, above those indiscriminately ascribed to all the candidates.

\section{References}

[1] Todorov, A., Mandisodza, A.N., Goren, A. and Hall, C.C. (2005) Inferences of Competence from Faces Predict Election Outcomes. Science, 308, 1623-1626. https://doi.org/10.1126/science.1110589

[2] Evans, J.S.B.T. (2003) In Two Minds: Dual-Process Accounts of Reasoning. Trends in Cognitive Sciences, 7, 454-459. https://doi.org/10.1016/j.tics.2003.08.012

[3] Evans, J.S.B.T. (2008) Dual-Processing Accounts of Reasoning, Judgment, and Social Cognition. Annual Review of Psychology, 59, 255-278. https://doi.org/10.1146/annurev.psych.59.103006.093629

[4] Stanovich, K.E. (2004) The Robot's Rebellion: Finding Meaning in the Age of Darwin. Chicago University Press, Chicago.

https://doi.org/10.7208/chicago/9780226771199.001.0001 
[5] Todorov, A., Said, C.P., Engell, A.D. and Oosterhof, N.N. (2008) Understanding Evaluation of Faces on Social Dimensions. Trends in Cognitive Sciences, 12, 455460. https://doi.org/10.1016/j.tics.2008.10.001

[6] Kinder, D.R, Peters, M.D., Abelson, R.P. and Fiske, S.T. (1980) Presidential Prototypes. Political Behavior, 2, 315-337. https://doi.org/10.1007/BF00990172

[7] Olivola, C.Y. and Todorov A. (2010) Elected in 100 milliseconds: Appearance-Based Trait Inferences and Voting. Journal of Nonverbal Behavior, 34, 83-110. https://doi.org/10.1007/s10919-009-0082-1

[8] Tupes, E.C. and Christal, R.E. (1961) Recurrent Personality Factors based on Trait Ratings.USAF ASD Tech. Rep. No. 61-97, Lackland Airforce Base, TX: US Air Force.

[9] McCrae, R.R. and Costa P.T. (1987) Validation of the Five Factor Model of Personality across Instruments and Observers. Journal of Personality and Social Psychology, 52, 81-90. https://doi.org/10.1037/0022-3514.52.1.81

Submit or recommend next manuscript to OALib Journal and we will provide best service for you:

- Publication frequency: Monthly

- 9 subject areas of science, technology and medicine

- Fair and rigorous peer-review system

- Fast publication process

- Article promotion in various social networking sites (LinkedIn, Facebook, Twitter, etc.)

- Maximum dissemination of your research work

Submit Your Paper Online: Click Here to Submit

Or Contact service@oalib.com 